\title{
TNF- $\alpha$ promoter polymorphism: a factor contributing to the different immunological and clinical phenotypes in Japanese encephalitis
}

\author{
Sujit Kumar Pujhari ${ }^{1}$, Radha Kanta Ratho ${ }^{*}$, Sudesh Prabhakar ${ }^{2}$, Baijayantimala Mishra ${ }^{1}$ and Manish Modi
}

\begin{abstract}
Background: More than three billion populations are living under the threat of Japanese encephalitis in South East Asian (SEA) countries including India. The pathogenesis of this disease is not clearly understood and is probably attributed to genomic variations in viral strains as well as the host genetic makeup. The present study is to determine the role of polymorphism of TNF-alpha promoter regions at positions $-238 \mathrm{G} / \mathrm{A},-308 \mathrm{G} / \mathrm{A},-857 \mathrm{C} / \mathrm{T}$ and $-863 C / A$ in the severity of Japanese encephalitis patients.

Methods: Total of 142 patients including 66 encephalitis case (IgM/RT-PCR positive), 16 fever cases (IgM positive) without encephalitis and 60 apparently healthy individuals (IgG positive) were included in the study. Polymerase chain reaction restriction fragment length polymorphism (PCR-RFLP) using site specific restriction enzymes were implemented for polymorphism study of TNF alpha promoter.

Results: Following the analysis of the digestion patterns of four polymorphic sites of the TNF- alpha promoter region, a significant association was observed between the allele -308A and -863C with the patients of Japanese encephalitis.

Conclusions: TNF- alpha $308 \mathrm{G} / \mathrm{A}$ has been shown to be associated with elevated TNF- alpha transcriptional activity. On the other hand, polymorphism at position -863C/A in the promoter region has been reported to be associated with reduced TNF- alpha promoter activity and lower plasma TNF levels. As per the literature search, this is the first study to identify the role of TNF- alpha promoter in JE infection. Our results show that subjects with $308 \mathrm{~A}$ and $-863 \mathrm{C}$ alleles are more vulnerable to the severe form of JE infection.
\end{abstract}

\section{Background}

Japanese encephalitis (JE) is an important flaviviral disease of public health concern in Eastern and South-East Asian (SEA) countries. Approximately 50,000 cases are being reported annually to $\mathrm{WHO}$ with a case fatality of 10,000 cases [1]. On account of globalization and climatic change, there is a gradual spread of the virus into naïve geographical areas including Australia and UK, however, fortunately there is no report of local spread of JE in UK $[2,3]$. In the past, the neurotropic nature of Japanese encephalitis virus (JEV) often posed epidemic threats of acute encephalitic syndrome (AES) in SEA countries including the Indian subcontinent $[4,5]$.

\footnotetext{
* Correspondence: virology_pgi@yahoo.com

'Department of Virology, Postgraduate Institute of Medical Education and Research, Chandigarh 160012, India

Full list of author information is available at the end of the article
}

Commonly the spectrum of JEV infection ranges from an asymptomatic infection to meningoencephalomyelitis with cortical damage and cord lesions. An overt case of JE carries a poor prognosis with a mortality of $10-30 \%$; one third of recovered cases land into neurological sequelae whereas complete recovery is expected in the remaining one third of patients [6].

Tumor necrosis factor is a multifunctional pro-inflammatory cytokine with a role in modulation of acute inflammation and host innate immunity. Its association towards disease progression has well been observed in several acute and chronic infections and autoimmune diseases. The reactivation of latent tuberculosis following treatment with anti-TNF antibody (Infliximab) has been reported [11], indicating TNF as a key cytokine towards the development of resistance to the tubercle bacilli and other intracellular pathogens. Even an excess

\section{C) Biomed Central}


production of TNF often proved to be detrimental in cerebral malaria, erythema nodosum leprosum and leishmaniasis [12-17].

The variations in the capacity to produce cytokines in different individuals have been attributed to the existence of polymorphisms within the regulatory regions or signal sequences of the cytokine genes. The present study aimed to associate the role of TNF- $\alpha$ promoter regions at positions $-238,-308,-857$ and -863 with disease progression and outcome in patients with Japanese encephalitis. The single nucleotide polymorphisms (SNPs) have been targeted because of their putative role on the promoter activity which might influence the TNF- $\alpha$ production and immunologic homeostasis.

\section{Methods}

All the subjects ( $\mathrm{n}: 142$ ) included in the study were enrolled during the post monsoon period (AugustDecember 2007-2009) i.e. JEV transmission season with informed consent. Of the total, 66 were JE patients [IgM (n: 56)/RT-PCR (n: 10) positive] with encephalitic features collected from inpatients departments of PGIMER, Chandigarh, 16 were JE IgM positive cases who presented with acute febrile illness and the rest ( $n: 60$ ) were apparently healthy subjects previously exposed to JEV infection (confirmed by detection of JEV specific IgG antibody) collected from the rural areas endemic to Japanese encephalitis belonging to the neighboring rice growing states of Chandigarh. A clinical-case definition of JE was followed as per National Vector Borne Disease Control Programme, Govt. of India. Febrile illness of variable severity associated with neurological symptoms ranging from headache to meningitis or encephalitis were labeled as Acute Encephalitic Syndrome (AES). Symptoms can include headache, fever, meningeal sign, disorientation, coma, tremor, generalized paralysis, hypertonia and loss of coordination. Patients with suspected AES showing JE specific IgM antibody in the cerebro-spinal fluid (CSF) only/in paired samples of CSF and blood or JEV RNA in CSF $[9,18]$ are labeled as confirmed JE cases whereas those with only JE IgM positivity in serum are considered as probable JE cases [19]. The possibility of cross-reactive antibodies to dengue virus was taken into account and all the samples (fever, encephalitis) were also screened for dengue specific IgM antibodies (Dengue specific IgM Ab ELISA; NIV, Pune, India) and were found to be nonreactive. From each subject, approximately $3 \mathrm{ml}$ of blood was collected aseptically by trained health personnel for genomic DNA extraction (1 ml anti-coagulated blood) and viral serology ( $2 \mathrm{ml}$ blood in sterile plain vial). The details of serology and viral genome detection procedures were described previously [9].
Genomic DNA was extracted as per the manufacturer's protocol using QIAGEN DNA extraction kit. For the detection of SNPs at TNF- $\alpha$ promoter region, gene specific PCR was performed followed by restriction fragment length polymorphism (PCR-RFLP). The positions $-863 \mathrm{C} / \mathrm{A},-857 \mathrm{C} / \mathrm{T},-308 \mathrm{G} / \mathrm{A}$, and $-238 \mathrm{G} / \mathrm{A}$ were amplified using the published primer sequences and amplification profiles [20]. These PCR products were further subjected to restriction digestion with respective restriction enzymes as shown in Table 1 and the digested products were observed in ethidium bromide stained 3\% agarose gel. The allelic type was determined according to the presence or absence of the digested product of the desired length. Adequate precautionary measures were taken for cross contamination during PCR amplification; RFLP and $50 \%$ of the samples were repeated to maintain the quality of the data.

\section{Statistical analysis}

The data was evaluated by chi-square $\left(\chi^{2}\right)$ analysis using standard statistical software with a $\mathrm{P}$ value of $<0.05$ being statistically significant. Genotypic frequencies were examined by Hardy-Weinberg equilibrium test. EPI version 6.2 was implemented for estimation of the $\chi^{2}$ value, odds ratios and $95 \%$ confidence intervals for genotypic and allelic frequencies.

\section{Results}

Demographic characteristics of the subjects

The male:female ratio in the encephalitis, fever and control groups were 55/11, 10/6 and 19/41 respectively. It was interesting to note that children below 16 years age group were more affected and males outnumbered the females in the group of patients with encephalitic features (Table 2).

Table 1 Restriction enzymes and digestion patterns for genotyping of TNF promoters

\begin{tabular}{llll}
\hline $\begin{array}{l}\text { Promoter } \\
\text { position }\end{array}$ & $\begin{array}{l}\text { Restioction } \\
\text { enzymes }\end{array}$ & $\begin{array}{l}\text { Digestion } \\
\text { patterns }\end{array}$ & Genotypes \\
\hline$-238 \mathrm{G} / \mathrm{A}$ & $\mathrm{Mspl}$ & 132,20 & $\mathrm{GG}$ \\
\hline & $152,132,20$ & $\mathrm{GA}$ \\
\hline$-308 \mathrm{G} / \mathrm{A}$ & Styl & 152 & $\mathrm{GG}$ \\
\hline & & 123,20 & $\mathrm{GG}$ \\
\hline & $143,123,20$ & $\mathrm{GA}$ \\
\hline$-857 \mathrm{C} / \mathrm{T}$ & Hincll & 143 & $\mathrm{AA}$ \\
\hline & 10625 & $\mathrm{CC}$ \\
\hline & 131,10625 & $\mathrm{CT}$ \\
\hline$-863 \mathrm{C} / \mathrm{A}$ & $\mathrm{Styl}$ & 131 & $\mathrm{TT}$ \\
\hline & 108,25 & $\mathrm{CC}$ \\
\hline & $133,108,25$ & $\mathrm{CA}$ \\
\hline
\end{tabular}


Table 2 Subject details

\begin{tabular}{lllll}
\hline & Encephalitis $(\mathbf{n}=\mathbf{6 6})$ & Fever $(\mathbf{n}=\mathbf{1 6})$ & Control $(\mathbf{6 0})$ & $\mathbf{X}^{\mathbf{2}} \mathbf{P}$ Value \\
\hline Age $($ Year mean \pm SD) & $16 \pm 12.543$ & $30.76 \pm 14.942$ & $21.72 \pm 10.187$ & $23.902 .001^{* *}$ \\
\hline Sex(Male/Female) & $55 / 11$ & $10 / 6$ & $19 / 41$ & $29.148 .001^{* *}$ \\
\hline Male/Female in \% & $83.3 / 16.7$ & $62.5 / 37.5$ & $31.7 / 68.3$ & \\
\hline
\end{tabular}

\section{Genotypic distribution and allelic frequency}

The genotypic and allelic frequencies of $-863 \mathrm{C} / \mathrm{A}$, -857C/T, -308G/A, and -238G/A were calculated (Table 3). Allele and genotypic frequencies were in HardyWeinberg equilibrium. The frequency distribution of the homozygous GG and heterozygous GA at -308 in encephalitis group was statistically significant when compared with fever (GG: $X^{2}=15.96, \mathrm{p}=0.001^{* * *}$, OR = 11.56, $95 \% \mathrm{CI}=2.61-58.51$; GA: $X^{2}=15.96, p=0.001^{* * *}$, $\mathrm{OR}=0.09,95 \% \mathrm{CI}=0.02-0.38)$ and control group (GG: $X^{2}=42.28, p=0.001^{* * *}, \mathrm{OR}=15.11,95 \% \mathrm{CI}=5.73$ 41.35; GA: $X^{2}=42.28, p=0.001^{* *}, \mathrm{OR}=00.07,95 \% \mathrm{CI}$ $=0.02-0.17)$. Again the distribution of the homozygous $\mathrm{CC}$ and heterozygous CA genotypes at -863 in encephalitis groups were statistically significant as compared with control group (CC: $X^{2}=23.51, p=0.001^{* *}$, OR = $0.12,95 \% \mathrm{CI}=0.04-0.33$; CA: $X^{2}=11.69, p=0.001 \%$, $\mathrm{OR}=9.74,95 \% \mathrm{CI}=1.96-65.38)$ (Table 4). Out of the 66 encephalitis patients, 9 had fatal outcome, of which 7 had the typical allelic distribution of $-308 \mathrm{~A}$ and $-863 \mathrm{C}$ genotypes.

Table 3 Genotypic and allelic frequencies of TNF- $\alpha$ polymorphism

\begin{tabular}{|c|c|c|c|c|}
\hline & & Control & Encephalitis & Fever \\
\hline \multirow[t]{4}{*}{-238} & $\mathrm{GA}$ & $4(6.7 \%)$ & $6(9.1 \%)$ & $2(12.5 \%)$ \\
\hline & GG & $56(93.3 \%)$ & $60(90.9 \%)$ & $14(87.5 \%)$ \\
\hline & G & 96.67 & 95.45 & 93.75 \\
\hline & $A$ & 3.33 & 4.5 & 6.25 \\
\hline \multirow[t]{4}{*}{-308} & GA & $9(15.0 \%)$ & $48(72.7 \%)$ & $3(18.75 \%)$ \\
\hline & GG & $51(85.0 \%)$ & $18(27.3 \%)$ & $13(81.25 \%)$ \\
\hline & G & 92.5 & 36.37 & 90.62 \\
\hline & A & 7.5 & 63.63 & 9.38 \\
\hline \multirow[t]{5}{*}{-857} & CC & $41(68.3 \%)$ & $50(75.8 \%)$ & $12(75 \%)$ \\
\hline & $C T$ & 19(31.7\%) & 10(15.2\%) & $4(25 \%)$ \\
\hline & $\pi$ & 0 & $6(9.1 \%)$ & 0 \\
\hline & $C$ & 84.16 & 83.33 & 87.5 \\
\hline & $T$ & 15.84 & 16.67 & 12.5 \\
\hline \multirow[t]{5}{*}{-863} & AA & $16(26.7 \%)$ & $5(7.6 \%)$ & $1(6.25 \%)$ \\
\hline & $C A$ & $14(23.3 \%)$ & $2(3.0 \%)$ & 0 \\
\hline & CC & $30(50.0 \%)$ & $59(89.4 \%)$ & $15(93.75 \%)$ \\
\hline & $A$ & 38.33 & 9.09 & 96.87 \\
\hline & C & 61.67 & 90.91 & 3.13 \\
\hline
\end{tabular}

\section{Discussion}

The human and murine model studies revealed that the outcome in infectious diseases is influenced by TNF- $\alpha$. In meningococcal meningitis patients, low TNF- $\alpha$ production is associated with tenfold increase in mortality [21] whereas the severity of the disease is directly proportional to the TNF- $\alpha$ levels in CSF and blood of JE patients [10].

The patho-physiology of the CNS entry by neurotropic viruses is still an enigma. The role of inflammatory cytokines has been amply emphasized towards disrupting the integrity of the blood brain barrier in West Nile Virus (WNV) infections. TLR-3 mediated expression of TNF- $\alpha$ leads to loss of integrity of the endothelial cells in the brain, possibly by mediating the passage of viral particles and virus loaded immune cells into the CNS $[22,23]$.

Following JE infection, approximately 1 in 300-1,000 persons would turn out with acute encephalitis and majority abort the infection sub clinically. The present study was aimed at the host factors governing pathogenesis of JE. There is no correlation between the disease severity and the circulating JE genotypes. However, a possible correlation is observed between the severity of JE and the level of JEV specific IgM antibody in the serum and CSF [10].

The TNF- $\alpha$ gene is located within the class III region of the major histocompatibility complex (MHC) between HLA-B and DR, (Figure 1) and its expression in the host is controlled in a regulated manner at the transcriptional as well as post transcriptional level. Polymorphism of TNF- $\alpha$ promoter region has been shown to play a role in the development of autoimmune diseases and several infections like malaria, leishmaniasis, hepatitis B virus, hepatitis $C$ virus, human papiloma virus etc. $[13,15,17,24]$.

The -308A allele in the TNF- $\alpha$ promoter (also known as TNF2) is a G/A transition and is the most studied $\mathrm{SNP}$ in this gene. In case of HBV infection, the presence of $-308 \mathrm{~A}$ and $-863 \mathrm{C}$ was associated with viral clearance [15], whereas SNP -238G has been shown to be associated with protection against chronic hepatitis in the Chinese and German population [14,16]. In hepatitis C virus infection, the haplotype -863C/-308G was associated with viral persistence in African Americans [12]. Similarly the existence of -308A SNP in pediatric population positively correlated with the severity of dengue viral infection in children. 
Table 4 Statistical comparison of Genotypic and allelic frequencies of TNF- $\alpha$ polymorphism between different groups

\begin{tabular}{|c|c|c|c|c|c|c|c|c|c|c|c|c|c|}
\hline \multirow[b]{2}{*}{ Loci } & \multirow[b]{2}{*}{ Genotype } & \multicolumn{4}{|c|}{ Control Vs Encephalitis } & \multicolumn{4}{|c|}{ Control Vs Fever } & \multicolumn{4}{|c|}{ Fever Vs Encephalitis } \\
\hline & & $\mathrm{X}^{2}$ Value & P-Value & OR & $95 \% \mathrm{Cl}$ & $\mathrm{X}^{2}$ Value & P-Value & OR & $95 \% \mathrm{Cl}$ & $\mathrm{X}^{2}$ Value & P-Value & OR & $95 \% \mathrm{Cl}$ \\
\hline \multirow[t]{2}{*}{-238} & GA & 0.25 & 0.43 & 0.71 & $0.16-3.06$ & 0.59 & 0.44 & 0.5 & $0.07-4.42$ & 0.17 & 0.48 & 1.43 & $0.18-9.28$ \\
\hline & GG & 0.25 & 0.43 & 1.4 & $0.33-6.29$ & 0.59 & 0.44 & 2 & $0.23-14.90$ & 0.17 & 0.48 & 0.7 & $0.11-5.64$ \\
\hline \multirow[t]{2}{*}{-308} & GA & 42.28 & $0.001^{* *}$ & 00.07 & $0.02-0.17$ & 0.13 & 0.48 & 0.76 & $0.15-4.17$ & 15.96 & $0.001^{* *}$ & 0.09 & $0.02-0.38$ \\
\hline & GG & 42.28 & $0.001^{* *}$ & 15.11 & $5.73-41.35$ & 0.13 & 0.48 & 1.31 & $0.24-6.47$ & 15.96 & $0.001^{* *}$ & 11.56 & $2.61-58.51$ \\
\hline \multirow[t]{3}{*}{-857} & CC & 0.86 & 0.35 & 0.69 & $0.29-1.62$ & 0.27 & 0.42 & 0.72 & $0.17-2.87$ & 0.001 & 0.58 & 0.96 & $0.24-4.13$ \\
\hline & $C T$ & 4.84 & 0.02 & 2.60 & $1.01-6.76$ & 0.27 & 0.42 & 1.39 & $0.35-5.39$ & 0.88 & 0.27 & 1.87 & $0.41-8.13$ \\
\hline & $\pi$ & 6.93 & 0.01 & & & 3.03 & 0.07 & 5.45 & $0.65-119.49$ & 26.7 & 0.001 & & \\
\hline \multirow[t]{3}{*}{-863} & $\mathrm{AA}$ & 8.25 & 0.04 & 4.44 & $1.38-15.09$ & 4.56 & 0.03 & & & 0.03 & 0.66 & 0.81 & \\
\hline & $C A$ & 11.69 & $0.001^{* *}$ & 9.74 & $1.96-65.38$ & 10.01 & $0.001^{* *}$ & 0.07 & $0.00-0.54$ & 0.50 & 0.64 & & \\
\hline & CC & 23.51 & $0.001^{* *}$ & 0.12 & $0.04-0.33$ & 0.59 & 0.44 & 0.5 & $0.07-4.42$ & 0.28 & 0.51 & 1.78 & $0.19-41.45$ \\
\hline
\end{tabular}

Single nucleotide polymorphisms (SNPs) in the TNF$\alpha$ promoter region at positions $-863 \mathrm{C} / \mathrm{A},-857 \mathrm{C} / \mathrm{T}$, -308G/A and -238G/A with reference to the transcription start site have been analyzed based upon the TNF secretion capacity. TNF- $\alpha-308 \mathrm{G} / \mathrm{A}$ has been shown to be associated with elevated TNF- $\alpha$ transcriptional activity. On the other hand, polymorphism at position $-863 \mathrm{C} / \mathrm{A}$ in the promoter region has been reported to be associated with reduced TNF- $\alpha$ promoter activity and lower plasma TNF levels. As per the literature search, this is the first study to identify the role of TNF- $\alpha$ promoter in JE infection. Our results show that subjects with $-308 \mathrm{~A}$ and $-863 \mathrm{C}$ alleles are more vulnerable to the severe form of JE infection. Logistic regression could not be performed in this study due to limited numbers of events which happens to be one of the limitations and warrants caution with regards to the conclusion.

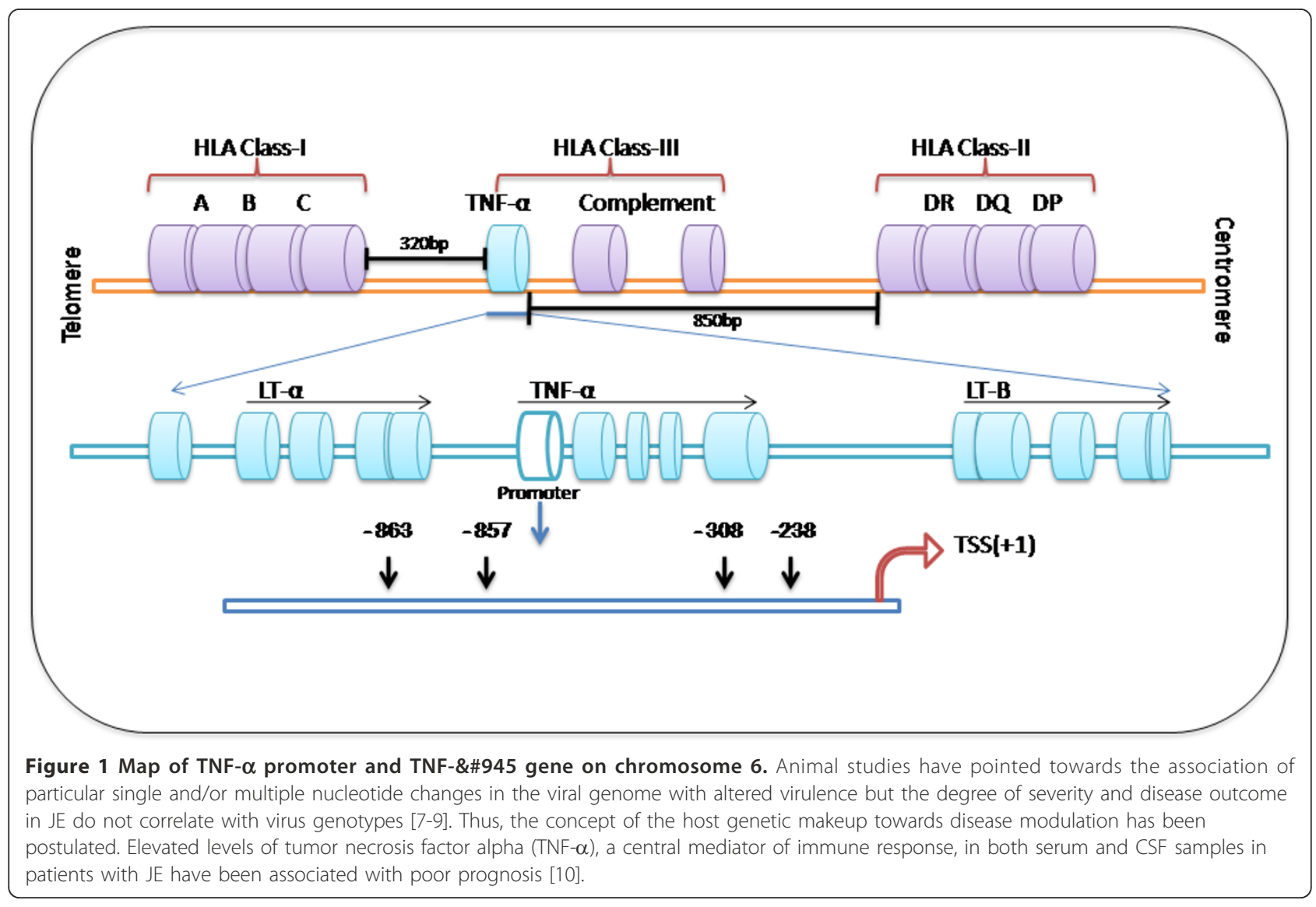


A combined effect of prolonged exposure to high level of pro-inflammatory cytokines (TNF- $\alpha$ ) combined with reduced release of anti-inflammatory cytokines IL-10 and IL-4 in encephalitis conditions may cause immunologic imbalance landed with poor prognosis [25]. Host genetic display of cytokine genes and their regulatory sequence alters the expression patterns of the different cytokines. In summary, the present study supports the potential role of genetic variation in the TNF- $\alpha$ promoter region in susceptibility to JEV infection.

\section{Conclusion}

Subjects with $-308 \mathrm{~A}$ and $-863 \mathrm{C}$ alleles were more vulnerable to the severe form of JE infection and of the total 9 deaths, 7 had $-308 \mathrm{~A}$ and $-863 \mathrm{C}$ allelic distribution. At the verge of entering into the era of personalized medicine, understanding the association of mutations with infectious disease is very important. This information will help the physician to become aware of a prior possible outcome of the patient and thus to follow an appropriate management protocol for the patients.

\section{Acknowledgements}

Sujit Kumar Pujhari is the recipient of senior research fellowship of Council of Scientific and Industrial Research, Govt of India. We would also like to acknowledge the technical support of Mr Amit Kumar. Part of this work was presented in the poster session at 14th International Congress on Infectious Diseases (ICID) 2010 at Miami, USA.

\section{Author details}

${ }^{1}$ Department of Virology, Postgraduate Institute of Medical Education and Research, Chandigarh 160012, India. ${ }^{2}$ Department of Neurology, Postgraduate Institute of Medical Education and Research, Chandigarh 160012, India.

\section{Authors' contributions}

SKP, RRK, SP, BMM and MM collectively designed the project work. SKP has done the sample collection and experimental work. SP and MM are the clinicians of this study. SKP, RRK, and BMM analyzed the data. All the authors contributed in manuscript writing. All authors read and approved the final manuscript.

\section{Competing interests}

The authors declare that they have no competing interests.

Received: 18 April 2011 Accepted: 26 January 2012

Published: 26 January 2012

\section{References}

1. Mackenzie JS, Gubler DJ, Petersen LR: Emerging flaviviruses: the spread and resurgence of Japanese encephalitis, West Nile and dengue viruses. Nat Med 2004, 10:S98-S109.

2. Hanna JN, Ritchie SA, Phillips DA, Lee JM, Hills SL, van den Hurk AF, Pyke AT, Johansen CA, Mackenzie JS: Japanese encephalitis in north Queensland, Australia, 1998. Med J Aust 1999, 170:533-536.

3. Petersen LR, Marfin AA: Shifting epidemiology of Flaviviridae. J Travel Med 2005, 12:S3-S11.

4. Solomon T, Ni H, Beasley DW, Ekkelenkamp M, Cardosa MJ, Barrett AD: Origin and evolution of Japanese encephalitis virus in southeast Asia. J Virol 2003, 77:3091-3098.
5. Rao P, Joshi K, Mishra B, Ratho RK, Kumar R: An outbreak of Japanese encephalitis in Haryana. J Commun Dis 2005, 37:78-81.

6. Solomon T: Recent advances in Japanese encephalitis. J Neuroviro/ 2003, 9:274-283.

7. Arroyo J, Guirakhoo F, Fenner S, Zhang ZX, Monath TP, Chambers TJ: Molecular basis for attenuation of neurovirulence of a yellow fever Virus/Japanese encephalitis virus chimera vaccine (ChimeriVax-JE). J Virol 2001, 75:934-942.

8. $\mathrm{Ni} \mathrm{H}$, Barrett AD: Molecular differences between wild-type Japanese encephalitis virus strains of high and low mouse neuroinvasiveness. $J$ Gen Virol 1996, 77:1449-1455.

9. Pujhari SK, Prabhakar S, Ratho RK, Modi M, Sharma M, Mishra B: A novel mutation (S227T) in domain II of the envelope gene of Japanese encephalitis virus circulating in North India. Epidemiol Infect 2010, 23:1-8.

10. Ravi V, Parida S, Desai A, Chandramuki A, Gourie-Devi M, Grau GE: Correlation of tumor necrosis factor levels in the serum and cerebrospinal fluid with clinical outcome in Japanese encephalitis patients. J Med Virol 1997, 51:132-136.

11. Long R, Gardam M: Tumour necrosis factor-alpha inhibitors and the reactivation of latent tuberculosis infection. Cmaj 2003, 168:1153-1156.

12. Thio CL, Goedert JJ, Mosbruger T, Vlahov D, Strathdee SA, O'Brien SJ, Astemborski J, Thomas DL: An analysis of tumor necrosis factor alpha gene polymorphisms and haplotypes with natural clearance of hepatitis C virus infection. Genes Immun 2004, 5:294-300.

13. Karplus TM, Jeronimo SM, Chang H, Helms BK, Burns TL, Murray JC, Mitchell AA, Pugh EW, Braz RF, Bezerra FL, et al: Association between the tumor necrosis factor locus and the clinical outcome of Leishmania chagasi infection. Infect Immun 2002, 70:6919-6925.

14. Li HQ, Li Z, LiU Y, Li JH, Dong JQ, Gao JR, Gou CY, Li H: Association of polymorphism of tumor necrosis factor-alpha gene promoter region with outcome of hepatitis B virus infection. World J Gastroenterol 2005, 11:5213-5217.

15. Kim YJ, Lee HS, Yoon JH, Kim CY, Park MH, Kim LH, Park BL, Shin HD: Association of TNF-alpha promoter polymorphisms with the clearance of hepatitis B virus infection. Hum Mol Genet 2003, 12:2541-2546.

16. Hohler T, Kruger A, Gerken G, Schneider PM, Meyer zum Buschenefelde KH, Rittner C: A tumor necrosis factor-alpha (TNF-alpha) promoter polymorphism is associated with chronic hepatitis B infection. Clin Exp Immunol 1998, 111:579-582.

17. McGuire W, Hill AV, Allsopp CE, Greenwood BM, Kwiatkowski D: Variation in the TNF-alpha promoter region associated with susceptibility to cerebral malaria. Nature 1994, 371:508-510.

18. Swami R, Ratho RK, Mishra B, Singh MP: Usefulness of RT-PCR for the diagnosis of Japanese encephalitis in clinical samples. Scand J Infect Dis 2008, 40:815-820.

19. Hills S, Dabbagh A, Jacobson J, Marfin A, Featherstone D, Hombach J, Namgyal P, Rani M, Solomon T: Evidence and rationale for the World Health Organization recommended standards for Japanese encephalitis surveillance. BMC Infect Dis 2009, 9:214.

20. Du T, Guo XH, Zhu XL, Li JH, Lu LP, Gao JR, Gou CY, Li Z, Liu Y, Li H: Association of TNF-alpha promoter polymorphisms with the outcomes of hepatitis B virus infection in Chinese Han population. J Viral Hepat 2006, 13:618-624.

21. Nassif $X$, Mathison JC, Wolfson E, Koziol JA, Ulevitch RJ, So M: Tumour necrosis factor alpha antibody protects against lethal meningococcaemia. Mol Microbiol 1992, 6:591-597.

22. Daffis S, Samuel MA, Suthar MS, Gale M Jr, Diamond MS: Toll-like receptor 3 has a protective role against West Nile virus infection. J Virol 2008, 82:10349-10358.

23. Wang T, Town T, Alexopoulou L, Anderson JF, Fikrig E, Flavell RA: Toll-like receptor 3 mediates West Nile virus entry into the brain causing lethal encephalitis. Nat Med 2004, 10:1366-1373.

24. Deshpande A, Nolan JP, White PS, Valdez YE, Hunt WC, Peyton CL, Wheeler CM: TNF-alpha promoter polymorphisms and susceptibility to human papillomavirus 16-associated cervical cancer. J Infect Dis 2005 , 191:969-976.

25. Biswas SM, Kar S, Singh R, Chakraborty D, Vipat V, Raut CG, Mishra AC, Gore MM, Ghosh D: Immunomodulatory cytokines determine the outcome of Japanese encephalitis virus infection in mice. J Med Virol 2010, 82:304-310. 


\section{Pre-publication history}

The pre-publication history for this paper can be accessed here:

http://www.biomedcentral.com/1471-2334/12/23/prepub

doi:10.1186/1471-2334-12-23

Cite this article as: Pujhari et al:: TNF- $\alpha$ promoter polymorphism: a

factor contributing to the different immunological and clinical

phenotypes in Japanese encephalitis. BMC Infectious Diseases 2012 12:23.

Submit your next manuscript to BioMed Central and take full advantage of:

- Convenient online submission

- Thorough peer review

- No space constraints or color figure charges

- Immediate publication on acceptance

- Inclusion in PubMed, CAS, Scopus and Google Scholar

- Research which is freely available for redistribution

Submit your manuscript at 